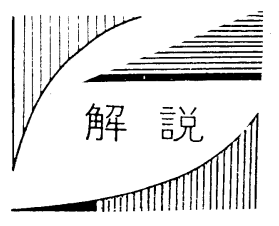

\title{
最近の大形船の構造強度とその 安全性についで
}

栘思吉郎 ${ }^{* *}$

船舶の大形化の傾向は, 最近著しいものがあります が, 船体の構造強度の観点からは, 従来の中・小形船 舶とくらべて, 大形船の場合に本質的な差異があると は考えられていません．大形船についても，中・小形 船と同様に部材のぜい性破壊, 疲労および座屈が問題 であり，これらの強度不足から損傷が発生することの ないように，使用材料に応じて部材の寸法が決定され ています。

それでは, 大形船も中・小形船も船体構造の安全性 について差異がないかといいますと，必ずしも同じで はないように思われます，その理由を，二，三あげて みますとつぎのようなことが考えられます.

(1) 船の耐用年数は, 従来, 20 年から 30 年ぐらい と考えられていますが，その期間中に構造部材は，漸 次, 腐食・衰耗して厚さが減少します。その量は, 部 材の使用環境によって左右されますが，ある一つの調 查結果として平均的にはつぎのような値であるといわ れています。

$$
\begin{array}{ll}
\text { クリーンバラストタンク内 } & 1 \mathrm{~mm} / \text { 年 } \\
\text { ダーテイバラストタンク内 } & 0.3 \mathrm{~mm} / \text { 年 }
\end{array}
$$

油タンク内 ピッチングコロージョンを除けば 一般的な腐食・衰耗はほとんどな い.

海事協会の鋼船規則では，貨物船の一般の構造部材 についでは $2.5 \mathrm{~mm}$, 油送船のタンク部分の一般の部 材については $3.5 \mathrm{~mm}$ の腐食・衰耗を前提に考えてい ます。

このような腐食・衰耗を考える場合に, 部材の厚さ の大小が腐食・衰耗の量に影響を与えるとは一般に考 えられていません，構造部材が 10 年間で $1 \mathrm{~mm}$ 衰耗す るとしますと, 厚さ $10 \mathrm{~mm}$ の部材は, 10 年後に建造 時の $90 \%$ の厚さとなりますが，厚さ $30 \mathrm{~mm}$ の部材は, 10 年後でも約 $97 \%$ の厚さが残っていることになりま す.

解体直前の老㱓船についても，ある程度以上の安全 性を保持させるためには, 建造時から解体時までの部

*原稿受付 弨和 46 年 7 月 3 日

昭和 46 年春季学術講演

** (財) 日本海事協会 (東京都港区赤坂 2-17-6)
材の衰耗を見越して建造時の寸法を決定する必要があ ります。船体構造部材の使用期間中の平均の衰耗量を かりに $3 \mathrm{~mm}$ と考えますと, 部材の平均の厚さが 10 $\mathrm{mm}$ 前後の小形船では, 使用期間経過後は $7 \mathrm{~mm}$ 前後 の板厚になりますが, この厚さで, 所要の強度が得ら れているとするならば, 建造時は, 所要強度よりも 40 \%厚い部材で作られていることになります。一方, 構 造部材の平均の厚さが $30 \mathrm{~mm}$ の大形船について同様 の考え方をしますと, 建造時は, 所要強度に対して 10 \%厚い部材で作られていることになります．このこと から, 建造後, 初期の時点では, 小形船は大形船にく らべてかなり余裕のある強度をもっていることになり ます。

大形船と小形船の強度上の安全性を建造の時点で考 えるか, 解体直前の時点で考えるか, あるいは, 使用 期間中の平均值で考元るかによって, 大形船と小形船 の安全性の相対的関係はそれぞれ異なったものとなり ます。

現状では，小形船は，新造船の時代はかなり無理な 使い方をしても強度上の耐力に余裕があるが，大形船 は，新造船といっても強度的にはそれほど余裕はない といえます。船を運航する場合に，大形船と小形船と では船路命と船体強度との相関がかなり違っていること を十分心得て，船の使用法を決定する必要があります。

（2）船体構造部材の寸法を決定する際，部材に生ず る各種の応力のうち, 卓越した応力をべースとして部 材寸法を決定するのが従来の手法であります．たとえ ば，フレーム，スチフナなどでは，支点間の最大曲げ 応力が設計基準応力ょりも大きくならないように寸法 を定めていますが，この設計基準応力は，一般には船 の大小，部材の断面形状とは関係なく定められていま す。これらの部材のせん断応力は, 卓越した值にはな りませんが, 船が大形になり, 部材の単位長さ当りの 荷重が増大するにつれて増大する傾向を示します。

たとえば，長さ一定の矩形ばりを考え，矩形ばりの 断面形状が相似であるとしますと，このはりに単位長 さ当り $w$ トンの等分布荷重が加わる場合, 最大曲げ応 
力が一定になるように，はりの寸法を定めれば，荷重 $w$ が増すにつれてはりの最大せん断応力は $w$ の立方根 に比例して増加します。

大形の油送船のトランスリングなどのけた類では, 曲げ応力およびせん断応力の両者とも卓越した值にな りますからここのようけたの設計では，曲げ応力お よびせん断応力の両方について設計基準応力が定めら れていますが，中・小形船のこのようなけたでは，設 計荷重によるせん断応力が設計基準応力よりもかなり 小さい值となっているのが一般の傾向として示されて います．また，これらのけたの軸応力も，せん断応力 と同様に船の大形化に伴って増大する傾向を示してい ます。

このようなことから，現在，構造規則で考えている 荷重条件のもとにおける応力状態としては，大形船の ほうが小形船よりもきびしい状態にあるといえます。 しかし, 現在, 構造規則で考えている荷重条件と, 船 が実際に海洋で受ける荷重との相関が十分は握されて いないこと，各種の応力が同時に存在する場合の構造 物の破壊強度が十分には解明されていないことから， 単に, 設計荷重にもとづく応力状態がきびしいという だけで, 大形船と小形船の強度上の安全性の比較を行 なうことはできません．

現在, 船が海洋で受ける荷重および船体構造の破壊 強度の研究・調査が進められていますから，数年後に は，その成果が船体構造設計あるいは構造規則に導入 されることと思います。

（3）船体強度は，すでに（1）および（2）で述べたと おり，大形船と小形船とで必ずしも全く同じではあり ませんし，また，同じ程度の大きさの船でも，その主 要寸法比, 構造様式などによって実際の強度には相違 がありますが, 基本的には各船とも同程度の強度をも つことが一応の目安として考えられており，大形船， 小形船を通じて多少のばらつきはあるとしても，その 強度水準にそれほど大きな差異はないといえます。し たがって，荒天時の運航方法が大形船も小形船もほぼ 同様であれば，強度上の安全性に関しても強度水準に おける差異と同様それほど大きな差異はないはずです が, 現実には, 運航面で感じられる安全性が, 大形船 と小形船とでかなり異なるため，運航方法に差が生じ， その結果として強度上の安全性に差があるような印象 を与える事象が起こることが考えられます，船は，一 般に大形船になるほど転覆しにくくなります. 小形船 では強度的には耐えられる荒天であっても, 復原性能 上, 耐えられない荒天が存在するため, しかも, 転覆
は船の安全上致命的であるため，荒天回避の努力が真 剣になされていると考えられます．船の長さが $100 \mathrm{~m}$ 以上になると転覆の恐れはほとんどなくなりますが, 長さ $150 \mathrm{~m}$ 程度の船までは, 荒天に遭遇すると甲板上 にかなり激しく波浪が打ち込むことになります。その 結果，甲板あるいは，甲板上のぎ装品に損傷を受けた り，甲板室の出入口とか窓が破損して浸水する場合も あります。

このようなことで, 程度の差はあるとしても, 自然 の脅威を身をもって体験せざるを得ないということは, それなりに，荒天に対する配慮が運航上なされること と思われます．長さ $200 \mathrm{~m}$ 以上の大形船になりますと， 復原性能は十分にあり，乾げんも大きく，船体強度か 耐えさえすれば荒天に対する恐れはほとんどなくなり ます。そのため，荒天回避は自然に対する恐れからで はなく, 目的港へ早く到達するための運航効率の面か らのみ考えられることになると思われます.

以上のことが，机上の空論であるならば，大形船の 強度上の安全性は, 小形船のそれとほとんど差はない といえますし，現実に以上のようなことが荒天時の運 航面に反映しているとするならば，強度水準はたとえ 同程度であっても強度上の安全性に関しては, 大形船 と小形船とで異なっているといえます.

以上, 大形船と小形船の安全性の差異について, 強 度上の観点から二，三の考え方を述べましたが，船が 設計荷重以下の荷重を受ける状態で使用されている限 りにおいては, 大形船も小形船も船体の強度上の安全 性に変りはないといえます。一方, 設計荷重を越えて 実際にどの程度の荷重まで耐えられるかという観点か ら, 安全性を考えるとしますと, 少なくとも新造後数 年間は，小形船のほうがその安全性に関して余裕があ るといえます。

つぎに，実際に就航している船舶の損傷に関して， 大形船と小形船とで差異があるかどうかを見てみます と, 損傷の種類および形態の定性的な面では, 大形船 および小形船を通じて特に差異は認められません。た だし，局部的な座屈損傷および疲労損傷の発生ひん度 は，大形船のほうが高く，大形船では実際の使用状況 下において局部的に各種応力の值が大きくなる機会が 多いことを示しています.これらの損傷の大部分は, 船の大形化によってフレーム，スチフナに加わる荷重 が増大し，これらの部材の支持点において，これらの 部材を支持しているけた類に伝えられる力が増大した 結果, 部材の支持点付近に発生したものであって, 部 材の強度不足というょりも, 荷重集中点における力の 伝達方法に対する配慮の不足によるものといえます. 
幸い,これらの損傷がけたの強度に与える影響は小 さく，けたの強度上の安全性を左右するようなもので はありませんが，船体保守の経済性の面からは，これ らの損傷の対策を十分検討する必要があるといえます．

以上，大形船の構造強度上の安全性について中・小 形船との比較において述べてきましたが，大形船の船 体の構造強度上の問題点として現在, 研究が進められ ている事項としてはつぎのようなものがあります．

（1）設計荷重として，できるだけ実際の荷重に近い ものを使用するため, 実際の荷重の推定精度を高 める.

（2）構造部材が荷重を受けた場合の計算応力と実際 の応力との対応を良くするため計算法の請度を高 める。

（3）構造部材に損傷が発生する限界荷重の大きさ, 繰返し数の推定精度を高め, 実働荷重下における 部材の損傷発生率の推定精度を高める.

（4）船舶が大形になると, 波による船体の縦曲げモ ーメントについて, 水平曲げモーメントの垂直曲 げモーメントに対する比率が増大する傾向がある が，これを船体縦強度上どのように扱うかの問題.

（5）船の長さが $300 \mathrm{~m}$ を越えると波による船体全体 の振動が問題となる場合がある.
（6）船の大形化に平行してタンクサイズの巨大化が 進んだこと，および船の幅と長さとの比が増大す る傾向にあることから生ずる横強度部材の強制変 形量の問題.

（7）大形コンテナ船の船体のねじれの問題.

以上のような問題について，各国においてそれぞれ 研究が行なわれていますが，このような研究の成果が 得られた段階においても, 船体の強度上の安全性は, 経験的に推測する域を出ることはできません．その理 由は, 申すまでもなく, 海洋に存在する荒天の極值を 知ることができないこと，船がその生涯に遭遇する荒 天の種類、ひん度を知ることができないことでありま す.

このことから, 大形船の安全性を, 強度上の安全性 のみによって確保しょうとすることには, 問題がある といえます，客船におけると同様，大形船についても 船舶の可浸性（船体が破損して浸水した場合の沈没し にくさ)，救助体制などを考慮して船舶の必要な安全 性を確保するのに最適な強度水準を荒天に遭遇するひ ん度と関連づけて決定することが船舶の構造強度と 安全性に関する今後の重要な課題であると考えられま す. 